\title{
49. Collybia Nameko, sp. nov.: a new Edible Fungus of Japan.
}

\author{
By Tokutaro ITo, Sc. D., F.L.S.
}

(Rec. March 4, 1929. Comm. by M. MrYoshi, M.I.A., March 12, 1929.)

Among a great variety of edible fungi to be found in Japan none are so remarkable as a few species which make their appearance in the depth of winter.

There exists in the north-eastern part of Japan particularly in the prefectures of Miyagi, Fukushima, etc., a species of winter mushroom populary known by the name of "Nameko." It is considered a delicacy by the inhabitants of these districts, and is consumed by them in great quantity, not only on account of its delicious flavour, but also because it abounds when fresh vegetables are scarce.

My studies, which have occupied more than three years, both in my laboratory and in the native habitat of this fungus, have convinced me that it is a new species of Collybia, nearly allied to C. velutipes (Curt.) Quél., a species which abounds in Japan and is popularly known as "Yenoki-také," and of wider distribution not only in Japan, but also in North and South America and Europe, and with which the present species has hitherto been confused. A new scientific name, "Collybia Nameko," is consequently proposed for it. Its principal host is Fagus Sieboldii, and it differs from the hosts of C. velutipes, which are Celtis, Salix, and many other trees. The following diagnosis exhibits its essential characteristics, and other points of scientific interest.

\section{Collybia Nameko, sp. nov.}

Cæspitosa. Pileus $2-8 \mathrm{~cm}$. latus, fulvus, ad marginem pallidus, carnosus, primo convexus, deinde planus, glaber, viscosus, margine irregulari repandoque. Stipes $2-8 \mathrm{~cm}$. longus, $\frac{1}{2}-1 \mathrm{~cm}$. crassus, validus vel cavus, lutescens, tum fulvus, æqualis, flexus, cartilagineus, leviter striatus, glaber, non velutinus, proster pilos subulatos planos infrequentem ad basin stipitatis. Lamellæ adnatæ sæpe decurrens, pallido-flavæ, deinde fulvæ, ad marginem minute et dense ramulosæ. Caro alba vel lutescens, ad marginem tenuis, mollis. Sporæ albæ, leve viridescens, ellipsoideæ vel oblongo-ellipsoideæ, 4.4-6.6 $\mu$ longæ, $2.2-3.3 \mu$ latæ, $1-2$-guttulatæ. (v.v.) 
Edulis. Odor gratiosus; sapor suavis.

Nomina Jap.: Nameko, Namerako, vel Namesusuki.

Hab. in truncis Fagi Sieboldii, Broussonetiae papyriferae, etc. in Japonia boreali-orientali comprehendis præfectoris Miyagi, Fukushima, Akita, etc.

Stroma per totam hiemem persistens.

Proxima C. velutipedi (Curt.) Quél. (nom. Jap. ut Yenoki-také vocatur), sed differt stipite glabro, luteo-fulvo, nec velutino nec bædionigrescente; affinis C. tenuipedi Schweinitz, differt stipite glabro necnon viscosissimo.

\section{EXPLANATION OF FIGURES IN PLATE 147.}

\section{Collybia Nameko T. Ito.}

Fig. 1. Habit. Natural size.

Fig. 2. Longitudinal section of sporophore. Natural size.

Fig. 3. Gills. Enlarged.

Fig. 4. Flat subulate hairs at the base of stipe. Enlarged.

Fig. 5. Spores. Highly magnified.

Fig. 6. Young sporophore enclosed within mucilaginous sac. Enlarged.

Fig. 7. Longitudinal section of same. Enlarged. 
No. 3.] Collybia Nameko, sp. nov.: a new Edible Fungus of Japan.

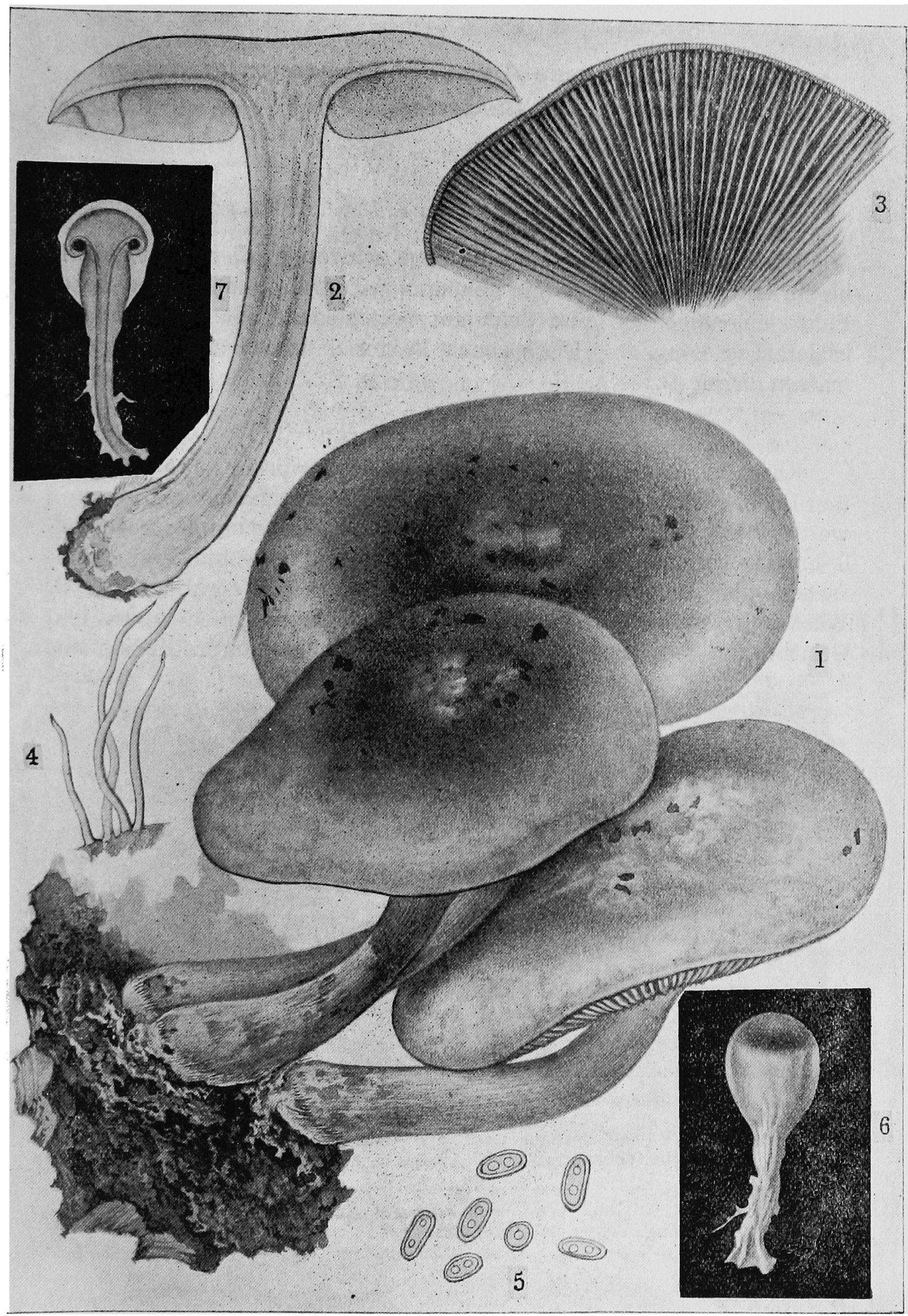

ITO-COLLYBIA NAMEKO SP. NOV. 